\title{
Turvemaiden fosforitalous maatalouden ja ympäristön kannalta
}

\author{
Into Saarela $^{1)}$, Martti Vuorinen ${ }^{2)}$ ja Markku Puustinen ${ }^{3)}$ \\ ${ }^{1)}$ MTT, kasvintuotannon tutkimus, maaperä ja kasvinravitsemus, 31600 Jokioinen, into.saarela@mtt.fi \\ ${ }^{2)}$ MTT, kasvintuotannon tutkimus, kasvintuotanto, 21500 Piikkiö, martti.vuorinen@mtt.fi \\ ${ }^{33}$ Suomen ympäristökeskus (SYKE), PL 140, 00251 Helsinki, markku.puustinen@ymparisto.fi
}

\section{Tiivistelmä}

Eloperäisten maiden osuus Suomen pelloista oli 1960-luvulla noin kolmannes eli yli 700000 hehtaaria (ha). Sen jälkeen suoviljelysten osuus on pienentynyt noin $0,4 \%$-yksikköä vuodessa ja on uusimpien viljavuustutkimusten mukaan $13,6 \%$ eli 308000 ha. Silmä- ja sormivaraisilla maalajimäärityksillä suurin osa eloperäisistä pelloista on luokiteltu multamaaksi (20-40\% orgaanista ainetta) ja turpeeksi (>40\% org.) vain 3,8\%-yksikköä, mikä edustaa 85000 ha:n peltoalaa. Sähköuunissa poltettaessa tapahtuvan painohäviön eli hehkutuskevennyksen mukaan kuitenkin noin puolet eli 150000 ha eloperäisten viljelymaiden nykyisestä pinta-alasta on turvetta.

Turpeen löyhä rakenne helpottaa juurten kasvua mutta kylmyys vaikeuttaa kasvien ravinteiden saantia varsinkin alkukesällä. Maatuneiden, tiiviiden turpeiden ja multamaiden märkyys voi häiritä juurten kehitystä ja ravinteiden ottoa etenkin orasvaiheessa, jolloin fosforin (P) niukkuus korostuu. Normaaleina kasvukausina ympäristötukeen oikeuttava P-lannoitus riittää hyviin satoihin fysikaalisilta ja kemiallisilta ominaisuuksiltaan edullisilla savetuilla soilla, mutta hiekkaisilla ja löyhillä turpeilla fosforia tarvittaisiin huonoimmissa maan viljavuusluokissa enemmän. Kun turvemaan kivennäisosa on vähäinen tai hyvin karkea eli niukasti aktiivista alumiinia ja rautaa sisältävä, fosfaatti-anionit pidättyvät siihen heikosti. Tällaisessa maassa P-lannoituksen välitön hyväksikäyttöaste nousee korkeaksi ja ylimäärinä lisätty lannoitteen ja lannan fosfori on altista huuhtoutumaan.

Sekä savetut että luonnostaan runsaasti alumiinia ja rautaa sisältävät turpeet pidättävät liukoista fosforia melko tehokkaasti. Maatumattomissa rahkaturpeissa fosfaatti-ionien kiinnityspaikkoja ei kuitenkaan ole juuri lainkaan, ja myös eräistä saraturpeista fosforia huuhtoutuu helposti. Savetuilla soilla fosfaatti-ionit voivat liikkua veden mukana syvemmällä maassa paljon helpommin kuin kyntökerroksessa. Pitkään jatkuneen lannoituksen seurauksena useiden turvemaiden liukoisen fosforin pitoisuus onkin suurentunut myös muokatun kerroksen alapuolelta, mikä Suomen kivennäismailla on hyvin vähäistä. Fosforin huuhtoutumisen välttämiseksi paksuturpeisten soiden P-tila tulisi selvittää myös jankkokerroksesta. Ympäristön kannalta tärkeää on se, että kun erilaisten maiden asetaattiliukoisen fosforin pitoisuus eli viljavuustutkimuksen P-luku on yhtä suuri, heikosti fosforia pidättävissä turpeissa maanesteen P-pitoisuus on kymmeniä kertoja suurempi kuin kivennäismaissa. Jos tällaisten maiden fosforitase on pitkään vahvasti positiivinen, ne voivat rehevöittää vesistöjä monta kertaa enemmän kuin pinta-alaosuuttaan vastaavasti.

Tutkimuksessa tarkastellaan turvemaiden fosforitaloutta ja sen parantamismahdollisuuksia tavoitteena sekä maatalouden että ympäristön kannalta suotuisa suopeltojen viljely. Keskeisenä aiheena on lannoituksen optimointi ja vesistöjen rehevöitymisen välttäminen viljavuustutkimuksen fosforiluvun tulkintaa tarkentamalla. Turvepeltojen fosforitaloutta parantavia maanhoito- ja viljelytoimia ovat kivennäismaan lisäys ja kalkitus sekä fosforin suhteen vaatimattomien kasvien viljely niukalla fosforilannoituksella.

\section{Asiasanat}

Alumiini, eloperäinen aines, fosforinpidätys, huuhtoutuminen, kivennäisosa, lannoitustarve, rauta 


\section{Johdanto}

Lisääntyvän väestön ravinnontarpeen tyydyttäminen tapahtui 1950-luvulle saakka pääasiassa viljeltävää peltoalaa laajentamalla, mikä merkitsi mittavaa soiden raivaamista pelloksi. Turvemaiden viljelykelpoisuutta sekä fysikaalisia ja kemiallisia ominaisuuksia ja niiden parantamista on tutkittu viljelykokeiden ohella tarkoilla mittauksilla ja kemiallisilla analyyseillä yli sata vuotta. Hattulan Leteensuolle vuonna 1902 perustettu Suontutkimusyhdistyksen suontutkimusasema oli Suomen ensimmäinen "nykyaikainen" kasvinviljelykoeasema. Maataloudellisen suontutkimuksen huippukausi jatkui 1960-luvulle saakka, jonka jälkeen turvetutkimukset ovat painottuneet kasvihuoneviljelyyn sekä neuvontaa palveleviin rutiinitesteihin eli viljavuustutkimuksiin. Maineikkaimpia suon ja turpeen tutkijoita ovat Helsingin yliopiston maanviljelyskemian professori ja rehtori Erkki Kivinen (1933), professori Viljo Puustjärvi (1991) ja vuorineuvos Yrjö Pessi (1966) sekä fosforin osalta professori Armi Kaila (1956a, 1956b ja 1959). Diplomi-insinööri Eugen Barkoff'in (1959) automaattisella laitteellaan määrittämät maan fosforifraktiot kuvaavat hyvin paitsi eloperäisten maiden eroja kivennäismaihin verrattuna myös turpeiden fosforitalouden suurta maalajin sisäistä vaihtelua.

Vanhimmat suopellot on raivattu runsasravinteisille suotyypeille, joilta saatiin kohtalaisia satoja niukallakin lannoituksella (Salonen ja Tainio 1957). Kaikkein runsasfosforisimmat turpeet tuottivat jopa täysiä satoja ilman fosforilannoitusta (Valmari 1957). Myöhemmin on raivattu pelloksi hyvinkin karuja soita, joiden sadontuottokyky perustuu kokonaan monipuoliseen lannoitukseen (Salonen ja Tainio 1957, Virkajärvi ja Huhta 1993). Huonoimpien turpeiden viljelyn lopettaminen, laihan pintaturpeen maatuminen ja lannoitefosforin kertyminen ovat parantaneet eniten juuri suopeltojen fosforitilaa ja vähentäneet niiden lannoitustarvetta (Saarela ja Elonen 1982, Saarela ym. 1995). Laihojen, vähän sorptioaktiivista alumiinia ja rautaa sisältävien turpeiden heikko fosforinpidätyskyky todettiin jo 1950-luvulla (Kaila 1959). Myöhemmin osoitettiin, että tällaisissa turpeissa maanesteen fosforipitoisuus on asetaattimenetelmällä määritettyyn maan fosforilukuun verrattuna paljon suurempi kuin kivennäismaissa (Sippola ja Saarela 1992). Turvepellot, jotka biologisesti hajotessaan tuottavat ilmakehän lämpötilaa kohottavaa hiilidioksidia, voivat olla myös huomattavia liukoisen fosforin lähteitä ja rehevöittää vesistöjä paljon enemmän kuin pinta-alaosuuttaan vastaavasti (Kuntze ja Scheffer 1979, Finck 1992, Huhta ja Jaakkola 1993, Kemppainen 1994).

Viljavuustutkimuksen tilastot osoittavat turvepeltojen kemiallisia ominaisuuksia ja pinta-aloja maan eri puolilla (Kurki 1972, Kähäri ym. 1987, Myllys ja Sinkkonen 2004). Maanäytteistä tehtävät silmäja sormivaraiset maalajimääritykset eivät kuitenkaan osoita todellisia maalajien osuuksia yhtä luotettavasti kuin systemaattiseen otantaan ja hehkutuskevennykseen perustuvat tutkimukset (Juusela ja Wäre 1956, Puustinen ym. 1994). Viljavuustutkimuksen fosforilukujen nykyinen tulkinta perustuu lannoitustarpeen osalta vuosien 1950-1976 paikalliskokeisiin (Sippola ja Marjanen 1978, Sippola 1980) ja vuosina 1977-1994 tehtyihin monivuotisiin lannoituskokeisiin (Saarela ym. 1995) sekä ympäristön kannalta arveluttavan korkean pitoisuuden osalta Sippolan ja Saarela (1992) laboratoriotutkimuksiin. Tohmajärven Valkeasuolla polttoturpeen jättöalueella (Virkajärvi ja Huhta 1993) ja Jokioisten savetulla saraturpeella tehdyt kenttätutkimukset (Saarela 1992) kuvaavat maan ja kasvin fosforitaloutta tavanomaisesta poikkeavissa maaperä- ja sääoloissa.

Vuosikymmenten kuluessa kertynyt tutkimusaineisto sisältää runsaasti käyttökelpoista tietoa, joka auttaa turvemaiden fosforitalouden ymmärtämistä ja hallintaa niin maatalouden kuin ympäristönkin kannalta. Tilojen ravinnehuoltoon välittömästi liittyvänä aiheena turvemaiden lannoitustarvetta ja fosforin huuhtoutumisriskiä tarkastellaan viljavuustutkimukseen kuuluvan, happamalla asetaattiuutolla määritetyn maan fosforiluvun perusteella.

\section{Turvepeltojen pinta-ala ja kivennäisaineksen osuus}

Neljäkymmentä vuotta sitten suopeltojen osuus Suomen peltoalasta oli noin kolmannes eli yli 700000 ha (Kurki 1972, Saarela ja Elonen 1982, Myllys ja Sinkkonen 2004). Vuosien 1966-1970 viljavuusnäytteistä eloperäisten maiden osuus oli 26,6 prosenttia, mutta suovaltaisten pohjoisten alueiden näytteet edustivat suurempaa peltoalaa kuin eteläisten. Maaseutukeskuksittain laskettuna 
eloperäisten maiden osuudeksi saatiin $30 \%$ (Saarela ja Elonen 1982), ja suopellot lienevät olleet aliedustettuina myös maaseutukeskusten lisällä. Viimeisten vuosikymmenten kuluessa multa- ja turvemaiden osuus on vähentynyt metsityksen ja turvekerroksen kulumisen takia ja on vuosien 19982002 viljavuustutkimusten mukaan 13,6 \% eli 308000 hehtaaria (Myllys ja Sinkkonen 2004). Eloperäisten maiden prosenttiosuus pelloista vaihtelee Lounais-Suomen alle neljästä prosentista Lapin yli kolmeenkymmeneen prosenttiin. Hehtaareina ilmaistuna suoviljelykset painottuvat LänsiSuomeen, sillä lähes $60 \%$ niistä sijaitsee Satakunnassa tai Pohjanmaalla. Turpeiden osuus on suurin pohjoisimmissa maakunnissa.

Viljavuustutkimuksen maalajimääritys perustuu silmä- ja sormivaraiseen arviointiin eikä ole yhtä täsmällinen kuin hehkutuskevennykseen eli sähköuunissa poltettaessa tapahtuvaan painohäviöön perustuva määritys. Myös näytetiheys voi vaihdella maalajeittain ja aiheuttaa vääristymiä. Systemaattiseen otantaan ja hehkutuskevennykseen perustuvan tutkimuksen mukaan (Puustinen ym. 1994) Suomen peltojen pintakerroksesta oli v. 1989-1992 eloperäisten maalajien osuus noin $21 \%$, joka oli puoliksi multamaata ja turvetta (Kuvan 1 alin käyrä). Muut käyrät osoittavat, että jankkokerroksessa oli kivennäisaineita keskimäärin paljon vähemmän kuin niiden päällä olevassa kyntökerroksessa. Joka toisessa eloperäisessä jankossa eloperäisen aineksen osuus oli yli $67 \%$, mutta pinnassa vain joka neljännessä, ja joka neljännessä pohjamaassa kivennäisaineita ole korkeitaan $9 \%$ kuivan maan painosta. Kun tällaisen turpeen kuivatilavuuspaino on monta kertaa pienempi kuin kivennäismaan, siinä on kivennäisaineita maatilavuutta kohti vain pari prosenttia kivennäismaiden sisältämästä määrästä. Koska liukoinen fosfori ei pidäty kemiallisesti maan orgaaniseen ainekseen vaan sorptioaktiiviseen alumiiniin ja rautaan, joita löyhissä, vähätuhkaisissa turpeissa on kovin vähän, huomattava osa jankkoturpeista mutta paljon pienempi osa pintaturpeista pidättää fosforia hyvin heikosti.
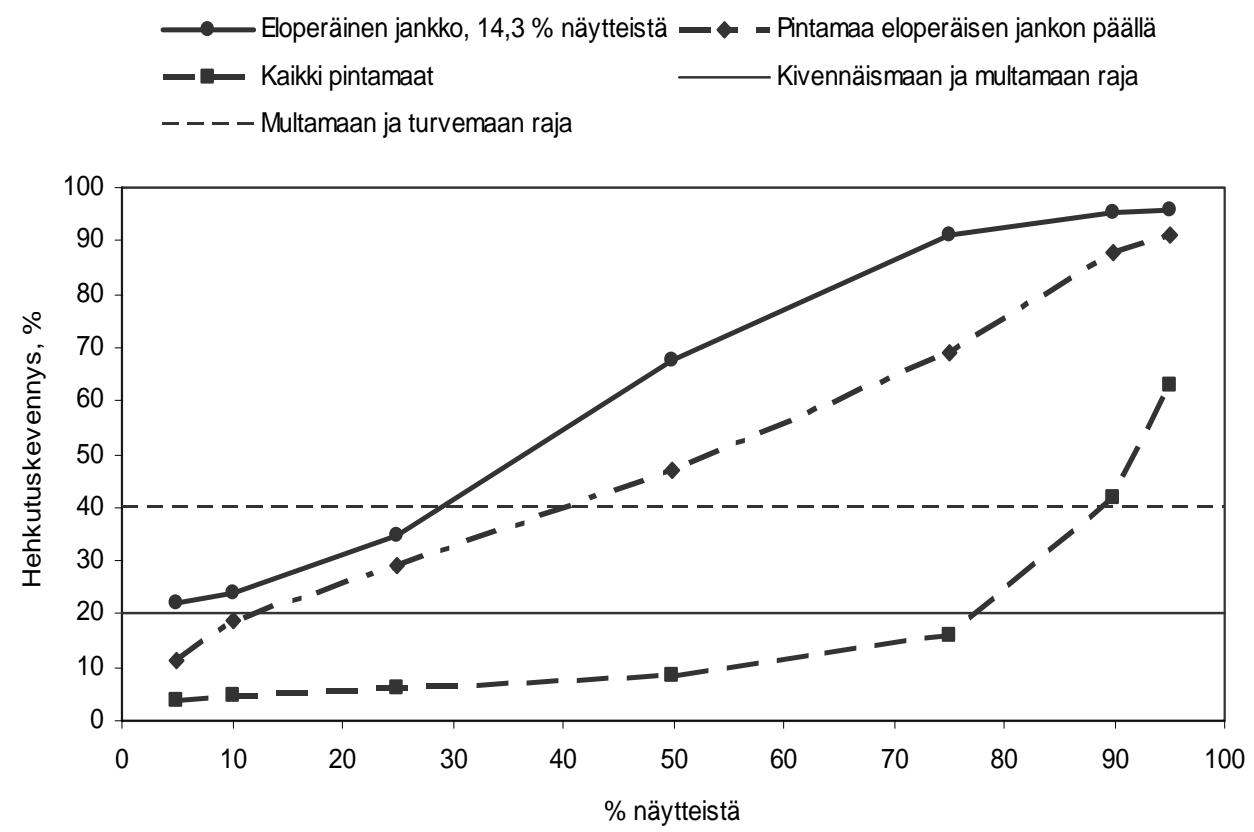

Kuva 1. Suomen peltojen pinta- ja pohjamaanäytteiden hehkutuskevennyksen summakäyrät Puustisen ym. (1994) fraktiilien mukaan piirrettyinä.

Viljavuustutkimukseen kuuluvan silmä- ja sormivaraisen maalajimäärityksen mukaan suurin osa eloperäistä maista on multamaata, ja turvetta on vain 85400 ha eli 3,8\%-yksikköä, mikä vastaa $28 \%$ viljeltyjen eloperäisten maiden pinta-alasta (Myllys ja Sinkkonen 2004). Turpeiden osuus viljavuusnäytteistä on paljon pienempi kuin v. 1989-1992 otetuista näytteistä hehkutuskevennyksellä määritetty $50 \%$. Tutkimusten erot johtuvat epäilemättä siitä, että aistinvaraisessa maalajimäärityksessä suuri osa maatuneista turpeista on luokiteltu multamaaksi. Eloperäisten maiden väheneminen on jatkunut vuosien 1989-1992 jälkeenkin, mutta turpeiden ja multamaiden osuudet 
näyttävät pienentyneen jokseenkin samassa tahdissa 1950-luvulta saakka (Juusela ja Wäre 1956, Puustinen ym. 1994). Turpeiden osuus eloperäisestä viljelymaista lienee edelleen noin $50 \%$ ja niiden pinta-ala lähes 150000 hehtaaria.

\section{Turvepeltojen fosforin määrä ja kemiallinen muoto}

Luonnontilaisten turpeiden fosforipitoisuus on maan kuivapainoon verrattuna melkein yhtä suuri kuin kivennäismaiden, mutta maatilavuutta kohti paljon pienempi. Kun suurin osa turpeen fosforista on hitaasti hajoavina orgaanina yhdisteinä, kasvien ravinnelähteenä olevaa epäorgaanista fosforia on 20 cm:n pintakerroksessa vain satakunta kiloa hehtaaria kohti (Kaila 1956a, 1956b). Kivennäismaissa lannoitefosfori kasvattaa merkittävästi vain epäorgaanisia fraktioita, mutta turpeessa myös orgaanisen fosforin määrä on muuttunut pitkäaikaisen superfosfaatin käytön seurauksena (Kaila ja Missilä 1956). Lannoituksen vaikutusta erilaisten turpeiden ja hiedan fosforifraktioihin esittää Kuva 2.

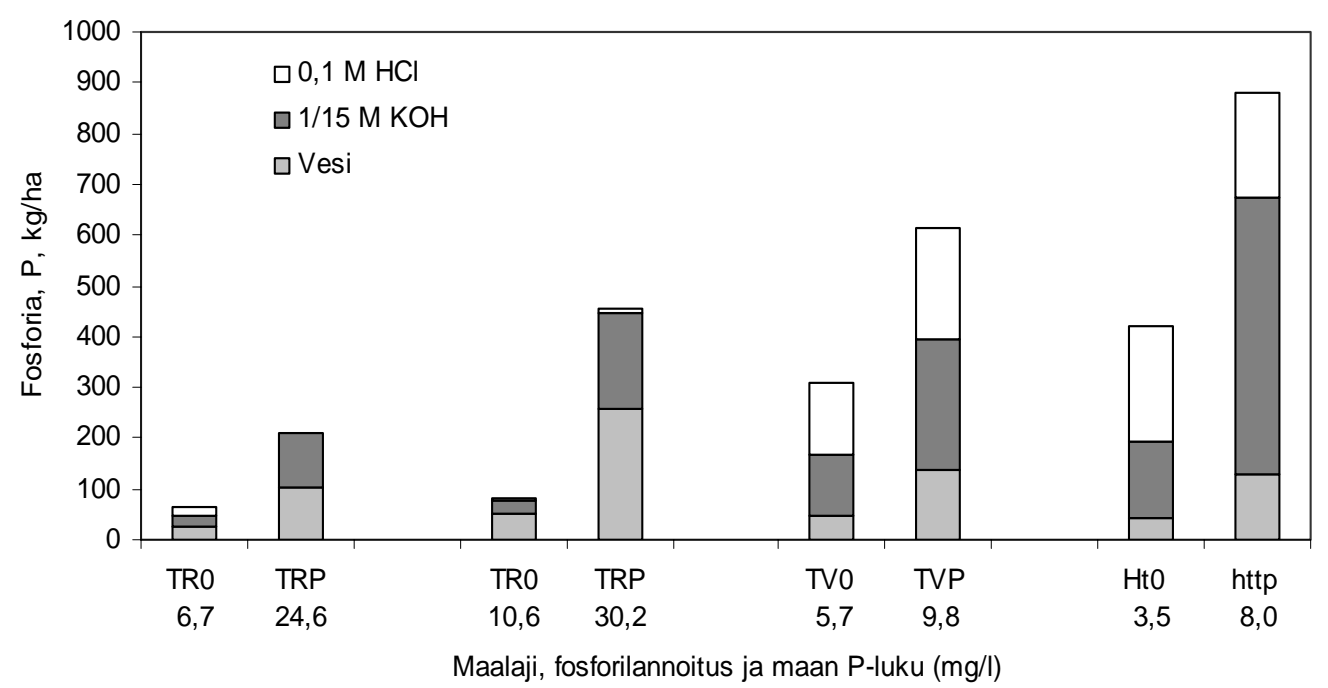

Kuva 2. Äskettäin raivatun (TR) ja vanhan (TV) turvemaan sekä hietamaan (Ht) fosforin vapautuminen deionisoituun veteen kuudessa tunnissa, sitten laimeaan kaliumhydroksidiin kolmessa tunnissa ja lopuksi happoon tavallisessa yhden tunnin uutossa (Barkoff 1959).

Automaattisella laitteella tehdyssä fraktioinnissa pitkän vesiuuton vaihtoehtona on lyhyempi $0,01 \mathrm{M}$ kaliumkloridin kierrätys, jolloin fosforia irtoaa vähemmän. Kummankin uuton tehokkuus perustuu paljolti siihen, että liuoksesta poistetaan fosforin lisäksi kalsiumionit ja muut monenarvoiset kationit. Fraktiot osoittavat, että pitkään lannoittamatta viljeltyjen turpeiden epäorgaaniset fosforifraktiot ovat todella pieniä, mutta kuitenkin suhteellisen heikosti pidättyneitä. Lisätyllä kivennäismaalla parannetussa vanhassa turvepellossa oli enemmän emäsliukoistakin fosforia ja kivennäismaan tapaan myös happoliukoista apatiitin fosforia. Lisätyn fosforin kertyminen emäsliukoiseen fraktioon eli kiinnittyminen fosfaattiligandeina alumiinin ja raudan oksihydroksideihin on tyypillistä sekä kivennäismaille että eloperäisille maille. Laihoista turpeista, joissa ei tällaisia fosforia pidättäviä aineita ole kuin nimeksi, saadaan asetaattimenetelmälläkin melko suuria fosforilukuja, ja tällaisista maista uuttuu fosforia suhteellisesti vielä enemmän veteen.

\section{Turvemaiden fosforilannoituksen tarve}

Taulukossa 1 esitetyt monivuotisten lannoituskokeiden tulokset osoittavat, että eloperäisten maiden fosforilannoituksen tarve vaihtelee paitsi viljavuustutkimuksen fosforiluvun mukaan myös muista syistä. Toholammin ja Ruukin kokeissa viljeltiin jatkuvasti fosforin suhteen vaateliasta aikaista ohraa, muualla viljeltiin myös nurmea tai kauraa ja Jokioisissa lisäksi ruista. Jokioisten vahvasti savetun saraturpeen suhteellisen runsaat sadot suurensivat ympäristötukeen oikeuttavaa fosforimäärää. Jokioisten koe ja muut vastaavat tulokset osoittavat (esim. Saarela ym. 1995, koe 72), että hyviin satoihin riittävät viljavuustutkimuksen fosforiluvut ovat pienimpiä savisilla multamailla ja savetuilla 
turpeilla. Vaalan ja Ruukin tulosten kanssa yhtäpitävästi karkeapohjaisten multamaiden ja ohuiden turpeiden optimilannoitus on ollut maan fosforipitoisuuteen verrattuna runsaampi (Saarela ym, 1995, kokeet 67, 68 ja 71, Virkajärvi ja Huhta 1993). Huonommilla turpeilla ympäristötukeen oikeuttava fosforilannoitus on maatalouden kannalta liian niukka. Myös paikallisissa nousevien fosforimäärien kokeissa fosforilannoitus on lisännyt satoja melko runsasfosforisillakin multa- ja turvemailla (Sippola ja Marjanen 1978, Sippola 1980).

Taulukko 1. Monivuotisten lannoituskokeiden tuloksia eloperäisilta mailta kokeiden loppupuolelta koevuosilta 7-17 (Saarela ym. 1995). Tukiraja osoittaa ympäristötukeen oikeuttavan lannoituksen enimmäismäärää uusien tukiehtojen mukaan. Optimilannoitusta vastaava maan fosforipitoisuus on määritetty viljavuustutkimuksen asetaattimenetelmän lisäksi hollantilaisella vesiuuttomenetelmällä.

\begin{tabular}{|c|c|c|c|c|c|c|c|c|c|c|c|}
\hline \multirow[t]{2}{*}{ Koepaikka } & \multirow[t]{2}{*}{ Maalaji } & \multirow{2}{*}{$\begin{array}{l}\text { Org, } \\
\text { C, } \%\end{array}$} & \multirow{2}{*}{$\begin{array}{l}\mathrm{pH} \\
\mathrm{H}_{2} \mathrm{O}\end{array}$} & \multirow{2}{*}{\multicolumn{2}{|c|}{$\begin{array}{l}\text { Aset-P mg/1 } \\
\text { Pinta Pohja } \\
0-2020-40 \mathrm{~cm}\end{array}$}} & \multirow{2}{*}{$\begin{array}{l}\text { Sato* } \\
\text { yks./ha }\end{array}$} & \multicolumn{2}{|c|}{ Fosforia, $\mathrm{kg} / \mathrm{ha}$} & \multirow{2}{*}{$\begin{array}{l}\text { Suht.sato } \\
\text { Tuki- } \\
\text { rajalla }\end{array}$} & \multicolumn{2}{|c|}{ Maan P opt.lann. } \\
\hline & & & & & & & $\begin{array}{l}\text { Optimi* } \\
\text { SS } 97 \%\end{array}$ & $\begin{array}{l}\text { Tuki- } \\
\text { raja }\end{array}$ & & $\begin{array}{l}\text { Aset-P } \\
\mathrm{mg} / \mathrm{l}\end{array}$ & $\begin{array}{l}\text { Vesi-P } \\
\mathrm{mg} / \mathrm{l}\end{array}$ \\
\hline Tohmajärvi & Saraturve & 31,2 & 4,8 & 5,2 & 3,2 & $2900 \mathrm{ok}^{*}$ & 21 & 18 & 96 & 6,5 & 6,5 \\
\hline Toholampi & Saraturve & 24,9 & 4,8 & 6,5 & 3,1 & $2760 \mathrm{o}$ & 40 & 20 & 84 & 5,9 & 3,5 \\
\hline Vaala & Hiekk. sarat. & 15,0 & 4,6 & 8,0 & 3,2 & 6000 tim. & 30 & 18 & 95 & 10,3 & 14,4 \\
\hline Jokioinen & Savettu sarat. & 22,5 & 5,3 & 9,2 & 1,2 & $4310 \mathrm{okr}$ & 8 & 20 & 100 & 6,6 & 5,9 \\
\hline Jokioinen & Ed. kalkittuna & 22,5 & 5,5 & 9,2 & 1,2 & $4500 \mathrm{okr}$ & 8 & 20 & 100 & 6,2 & 5,9 \\
\hline Ruukki & Hiet. sarat. & 17,9 & 5,1 & 14,2 & 11,7 & 3400 o & 16 & 11 & 97 & 14,6 & 22,0 \\
\hline Keskimääri & & 22,3 & 5,0 & 8,7 & 4,7 & 3980 & 21 & 18 & 95 & 8,4 & 10,5 \\
\hline
\end{tabular}

\footnotetext{
* Viljasadot on laskettu kiloina hehtaarilta ja nurmisadot rehuyksikköinä. Hehtaarisadot ovat riittävällä fosforilannoituksella saatuja maksimisatoja, ja optimilannoitus tuotti satoa 97 prosenttia maksimista. $\mathrm{o}=\mathrm{ohra}, \mathrm{k}=\mathrm{kaura}, \mathrm{r}=$ syysruis
}

Taulukon 1 kokeet tehtiin happamilla mailla, mutta vaatimattomat viljalajikkeet ja heinät saavat fosforia asetaattiin uuttuvaan pitoisuuteen verrattuna parhaiten kohtalaisen happamista turpeista. Jokioisissa kokeen alussa levitetty kalkkimäärä 10 tn/ha tummensi kasvuston väriä ja paransi hiukan kasvua, mutta ei vaikuttanut maasta asetaattiin ja veteen uuttuneisiin fosforimääriin eikä lannoitustarpeeseen. Tutkittaessa samoja maita astiakokeessa runsas kalkitus oli pikemminkin haitallinen (Saarela ja Sippola 1990). Saman tutkimuksen vähemmän happamista turvemaista (Saarela ym. 1995, kokeet 66, ja 69) timotei sai fosforia vähemmän kuin asetaattimenetelmän P-luku osoitti.

Jokioisten monivuotisen fosforilannoituskokeen vieressä samalla lohkolla tutkittiin vuosina 1983-1986 perustettavan nurmen lannoittamista suurilla fosforimäärillä, jotka vastasivat suojaviljalle ja 3vuotiselle nurmelle suositeltua lannoitusta (Saarela 1992). Vuonna 1983 orasvaiheessa sattuneet sateet haittasivat ohran juurten kehitystä, ja tiheä juuristo ulottui aluksi vain parin sentin syvyyteen. Maan fosforivarojen hyödyntäminen oli tehotonta, ja vähän tavallista matalampaankin sijoitetun fosforin saanti ja vaikutus viivästyivät. Matalaan pintakerrokseen äestämällä mullattu suuri fosforimäärä nopeutti märissä oloissa oraiden kasvua tehokkaasti, eikä kylvön jälkeen pinnallekaan levitetty fosfori ollut paljon riviin sijoitettua tehottomampaa (Taulukko 2).

Tulokset osoittavat, että juurten toiminnan vaikeutuessa fosforin saanti oli kriittinen tekijä, joka tässä tapauksessa vaikutti voimakkaasti myös lopulliseen ohrasatoon. Koepaikan ojitus toimi erinomaisesti, mutta kriittisenä aikana sattuneet sateet aiheuttivat kuitenkin hienomuruisessa multamaan pinnassa liikamärkyyttä. Joillakin turvemailla märkyys ja hapen puute voivat johtua myös korkeasta pohjavedestä. Tiiviillä eloperäisillä mailla, jotka ovat alkukesällä paitsi kosteita myös kylmiä (Pessi 1966), lannoitteet kannattaa sijoittaa melko matalaan. Pienillä fosforimäärillä saadaan paras teho sijoitettaessa lannoite siemenriviin tai sen viereen 2-5 cm:n etäisyyteen (Järvi, A. 1995) 
Taulukko 2. Ohran fosforin saanti ja kasvu Jokioisten savetulla saraturpeella vuonna 1983, jolloin maa oli aikaisessa orasvaiheessa veden kyllästämää. Koe sijaitsi samalla lohkolla kuin taulukossa 1 esitetty koe, mutta koepaikka oli alavampi ja maan fosforiluku pienempi eli 5,6 mg/l. Samalla kirjaimella merkitys saman sarakkeen luvut eivät poikkea toisistaan merkittävästi (riski $5 \%$ ).

\begin{tabular}{|c|c|c|c|c|c|}
\hline \multicolumn{2}{|c|}{ Fosforilannoitus } & \multicolumn{2}{|c|}{ Oraiden fosfori ja kuiva-aine } & \multicolumn{2}{|c|}{ Puitu jyväsato } \\
\hline $\mathrm{kg} \mathrm{P} / \mathrm{ha}$ & Menetelmä & $\mathrm{P} \mathrm{kg} / \mathrm{ha}$ & Kuiva-aine, $\mathrm{t} / \mathrm{ha}$ & $\mathrm{P} \mathrm{kg} / \mathrm{ha}$ & Jyviä, t/ha \\
\hline 0 & - & $1.2 \mathrm{a}$ & $0.44 \mathrm{a}$ & $7.0 \mathrm{a}$ & $1.96 \mathrm{a}$ \\
\hline 50 & Sijoitus & $+1.0 \mathrm{~b}$ & $+0.15 \mathrm{~b}$ & $+3.6 \mathrm{~b}$ & $+0.94 \mathrm{~b}$ \\
\hline 100 & Sijoitus & $+1.0 \mathrm{~b}$ & $+0.16 \mathrm{bc}$ & $+4.8 \mathrm{bc}$ & $+1.27 \mathrm{bc}$ \\
\hline 200 & Sijoitus & $+1.8 \mathrm{~cd}$ & $+0.27 \mathrm{c}$ & $+6.4 \mathrm{~d}$ & $+1.62 \mathrm{~cd}$ \\
\hline 200 & Multaus & $+2.0 \mathrm{~d}$ & $+0.24 \mathrm{bc}$ & $+7.4 \mathrm{~d}$ & $+1.86 \mathrm{~d}$ \\
\hline 200 & Pintaan & $+1.3 \mathrm{bc}$ & $+0.13 \mathrm{~b}$ & $+5.6 \mathrm{~cd}$ & $+1.31 \mathrm{bc}$ \\
\hline
\end{tabular}

\section{Turpeiden fosforin huuhtoutumisriski}

Edellä todettu kivennäisosan määrän ja laadun vaihtelu aiheuttaa suuria, jopa monikymmenkertaisia eroja turpeen fosforinpidätyskyvyssä. Suotyypeistä sadeveden suolojen ja kuivalaskeuman varassa kehittyvien kohosoiden rahkaturpeet pidättävät fosforia kaikkein heikoimmin. Tällaisilla mailla salaojavesien liukoisen fosforin pitoisuudet ovat jopa sata kertaa niin suuria kuin kivennäismailla (Finck 1992). Myös eräiden saraturpeiden fosforinpidätyskyky on heikko (Kaila 1959). Sippolan ja Saarelan (1992) vahvasti rikastuneita maita koskevan tutkimuksen eloperäisillä mailla arveluttavan korkea maanesteen tasapainokonsentraatio $0,5 \mathrm{mg} / \mathrm{l}$ vastasi asetaattimenetelmän P-lukua $14 \mathrm{mg} / 1$, joka on yli kolme kertaa pienempi kuin kivennäismaiden vastaava kriittinen P-luku. Eloperäisten maiden maanesteen fosforin tasapainokonsentraation ja viljavuusluvun suhteita esitetään kuvassa 3 . Multamaiden pintakerroksen yhtälön kerroin 0,035 on noin nelinkertainen lievästi happamiin kivennäismaihin verrattuna ja pohjamaaturpeiden monikymmenkertainen, ja yksittäisissä turvemaissa esiintyy vielä suurempia maanesteen fosforipitoisuuksia.

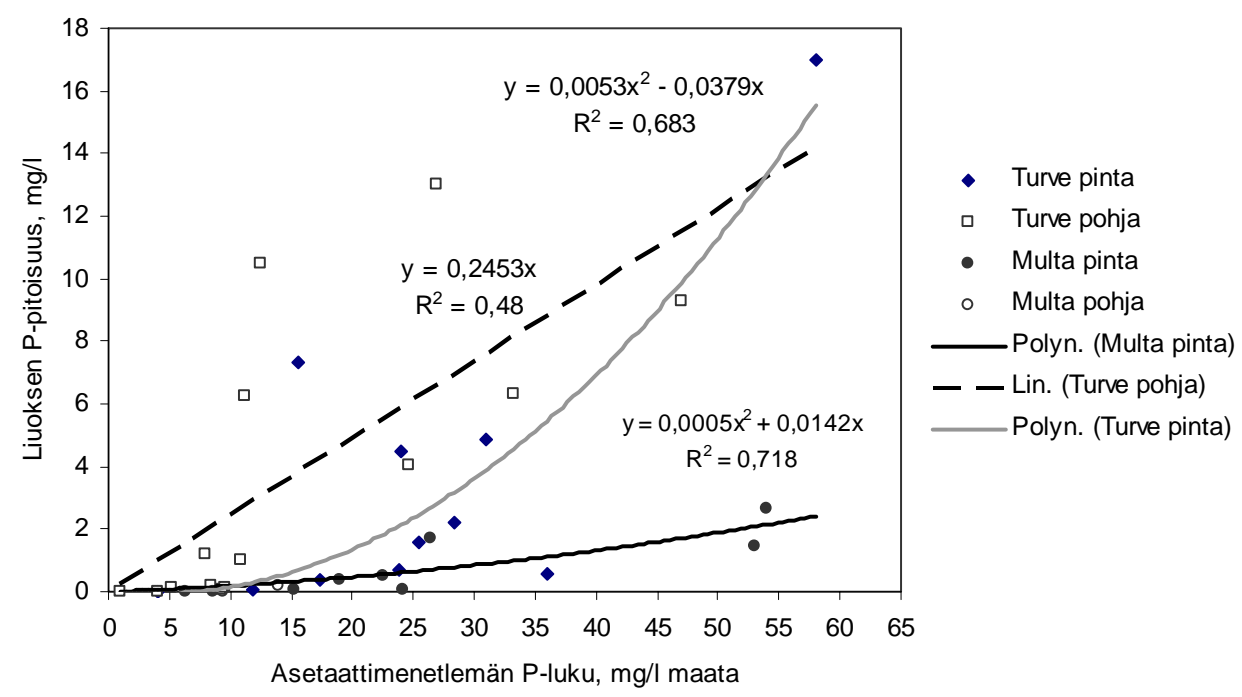

Kuva 3. Maanestettä vastaavan $0.005 \mathrm{M} \mathrm{CaCl}_{2}$-liuoksen fosforipitoisuuden ja viljavuustutkimuksen fosforiluvun suhteet eloperäisillä mailla (Sippola ja Saarela 1992). $1 \mathrm{mg} / \mathrm{l}$ vastaa $2,5 \mathrm{~kg} / \mathrm{ha} 250 \mathrm{~mm}: \mathrm{n}$ valunnassa.

Fosforinpidätyskyvyn ollessa kovin heikko pintamaan P-luku kasvaa vuodesta toiseen kertyvän positiivisen fosforitaseen seurauksen nopeasti, mutta kasvu ei jatku pitkään. Muokkauskerroksen alapuolisenkin maan P-luku alkaa muuttua lannoituksen vaikutuksesta selvästi jo parissa vuodessa. Pintamaan fosforivarojen ehtyessä kasvi pyrkii täyttämään vajauksen pohjamaasta ja taseen ollessa positiivinen suurenee myös pohjamaan fosforipitoisuus. Esimerkkejä tällaisista liukoista fosforia 
vuotavista maista ovat Vaalan hiekkainen saraturve (Taulukko 1, Saarela ym. 1995) ja Valkeasuon polttoturpeen jättöalue (Virkajärvi ja Huhta 1993). Huuhtoutumisriskin arviointia varten paksuturpeisista soista tulisi tutkia myös muokkauskerroksen alapuolisen turpeen liukoisen fosforin pitoisuus. Ylilannoitettujen turpeiden fosforin huuhtoutumista voidaan estää sorptioaktiivista alumiinia ja rautaa sisältävää kivennäismaata tai muuta sopivaa maanparannusainetta lisäämällä. Turvemaissa myös kalkitus vähentää fosforin huuhtoutumista, mikä johtunee alumiinin ja raudan orgaanisten yhdisteiden kanssa muodostamien kompleksiyhdisteiden aktivoitumisesta.

\section{Kirjallisuus}

Barkoff, E. 1959. Über die Fraktionierung der Bodenphosphate unter Verwendung eines automatischen Apparates mit Ionenaustauscher. Selostus: Maan fosfaattien fraktioimisesta automaattista laitetta ja ioninvaihtimia käyttäen. Acta Agralia Fennica 92.12. 35 p.

Finck, A. 1992. Dünger und düngung. 2. Auflage. VCH Verl., Weinheim. 488 p.

Huhta, H. \& Jaakkola, A. 1993. Viljelykasvin ja lannoituksen vaikutus ravinteiden huuhtoutumiseen turvemaasta Tohmajärven huuhtoutumiskentällä v. 1983-87. Maatalouden tutkimuskeskus, Tiedote 20/93. 66 p.

Juusela, T. \& Wäre, T. 1956. Suomen peltojen kuivatustila. Maatilahallitus, Maa- ja vesitekn. tutk. 8. 89 p.

Järvi, A. Ohralle ja kauralle fosforia kylvöriveihin. Koetoiminta ja Käytäntö 52: 10.

Kaila, A. 1956a. Phosphorus in various depths of some virgin peat lands. J. Scient. Agric. Soc. Finl. 28: 90-104.

Kaila, A. 1956b. Phosphorus in virgin peat soils. J. Scient. Agric. Soc. Finl. 28: 142-167.

Kaila, A. 1959. Retention of phosphate by peat samples.. J. Scient. Agric. Soc. Finl. 31: 215-224.

Kaila, A. \& Missilä, H. 1956. Accumulation of fertilizer phosphorus in peat soils. J. Sci. Agric. Soc. Finl. 31: 168-178.

Kemppainen, E. 1994. Naudan lietelannan ja ketun lannan ravinteiden huuhtoutuminen lysimetrikokeessa. Maatalouden tutkimuskeskus, Tiedote 16/94. 46 p.

Kivinen, E. 1933. Suokasvien ja niiden kasvualustan kasvinravintoainesuhteista. Acta Agralia Fenn. 27. 140 p.

Kurki, M. 1972. Suomen peltojen viljavuudesta II. Viljavuuspalvelu Oy. 182 p.

Kähäri, J., Mäntylahti, V. \& Rannikko, M. 1987. Suomen peltojen viljavuus 1980-1985. Viljavuusp. 105 p.

Myllys, M. \& Sinkkonen, M. 2004. Viljeltyjen turve- ja multamaiden pinta-ala ja alueellinen jakauma Suomessa. Suo 33: 53-60.

Pessi, Y. 1966. Suonviljely. WSOY, Porvoo. 139 p.

Puustinen, M., Merilä, E. Palko, J. \& Seuna, P. 1994. Kuivatustila, viljelykaäytäntö ja vesistökuormitukseen vaikuttavat ominaisuudet pelloilla. Vesi- ja ympäristöhall. Julk. - Sarja A. 323 p.

Puustjärvi, V. 1991. Kasvu ja sen hallinta kasvihuoneviljelyssä. Kauppapuutarhaliitto ry. 287 p.

Saarela, I. 1992. Agronomic efficiency and environmental effects of large doses of phosphorus with establishment vs. annual application in leys. Proc. $14^{\text {th }}$ Gen. Meet. Eur. Grassl. Fed., Lahti, Finland. p. 528-530.

Saarela, I. \& Elonen, P. 1982. Fosforilannoituksen porraskokeet 1977-1981. Maatalouden tutkimuskeskus, maanviljelyskemian ja -fysiikan laitos, Tiedote 16.55 p.

Saarela, I., Järvi, A., Hakkola, H. \& Rinne, K. 1995. Fosforilannoituksen porraskokeet 1977-1994. Maatalouden tutkimuskeskus, Tiedote 16/95. 94 p.

Saarela, I. \& Sippola, J. 1990. Inorganic leaf phosphorus and soil tests as indicators of phosphorus nutrition in cereals. Comm. Soil Sci. Plant Anal. 21: 1927-1943.

Salonen, M. \& Tainio, A. 1957. Fosforilannoitusta koskevia tutkimuksia. Valtion Maat.koet. Julk. 164. 104 p.

Sippola, J. 1980. Viljavuustutkimuksen tulkinnan ja nousevien fosfori- ja kaliummäärien kokeiden tulosten vertailu. Maatalouden tutkimuskeskus, maantutkimuslaitos, Tiedote $10.13 \mathrm{p}$.

Sippola, J. \& Marjanen, H. 1978. Viljavuusluokitaiset sadonlisäykset paikallisissa nousevien fosfori- ja kaliummäärien kokeissa. Maatalouden tutkimuskeskus, maantutkimuslaitos, Tiedote 3.16 p.

Sippola, J \& Saarela, I. 1992. Suomen maalajien fosforinpidätysominaisuudet ja niiden merkitys vesien kuormituksen kannalta. Vesi- ja ympäristöhallituksen monistesarja 359: 27-36.

Valmari, A. 1957. Über die edaphische Bonität von Mooren Nordfinnlands. Selostus: Pohjois-Suomen soiden maaperäboniteetista. Acta Agralia Fennica 88: 1-126

Virkajärvi, P. \& Huhta, H. 1993. Nurmen viljely polttoturvesoiden jättöalueilla. Timoteinurmen fosforilannoitus Tohmajärven Valkeasuolla. Maatalouden tutkimuskeskus, Tiedote 7/93. 27 p. 